\title{
Amy Winehouse: Back to Black and the Gothic
}

\author{
Adrian H. Sledmere \\ London College of Communication \\ a.sledmere@/cc.arts.ac.uk
}

\begin{abstract}
This article considers Amy Winehouse through the lens of the Female Gothic. With a specific focus on her song "Back to Black" (2007) and its accompanying video, an attempt is made to Gothicize the artist: to delineate an identity forged out of a variety of personalities and metaphors drawn from the Gothic. The various themes and tropes which emerge from this genre speak to a sense of continuity in terms of the structural constraints and anxieties that women face in society. To deploy the Gothic in relation to Amy Winehouse aims to give voice to gender related issues of power and autonomy. As part of the discussion I will foreground the significance of place in relation to both her narrative and music, by embracing a psychogeographic approach. This is to exploit a natural connection between Psychogeography and the Gothic by considering the possibility of darker currents and resonances via a relationship with the uncanny which they both share.
\end{abstract}

KeYWORDS: Amy Winehouse, Psychogeography, Gothic, Romanticism, the uncanny, Female Gothic

\section{Introduction}

To develop the Gothic focus of this article, I will explore the potential significance of the song "Back to Black" with reference to what I will periodically refer to as Winehouse's narrative or story. My aim is to reimagine her narrative within a Gothic, rock ' $n$ ' roll framework, one in which she can be seen as occupying different stock characters which in turn speak to the tension between the grotesque and the beautiful, itself emblematic of the Gothic. A few preliminary words are necessary to clarify what is and what is not being attempted here. I want to stress that the range of themes and ideas broached are not an exhaustive account of either Amy Winehouse's life or an attempt to make global claims about her existence based on the one musical text. However, my approach does recognize the elision between "star persona and song character" which was characteristic of Amy Winehouse (Dibben 2009: 328). 
The already Gothic nature of "Back to Black" is consistent with a kind of occulted vision of Amy Winehouse's life. Beginning with the notion of Romanticism I want to establish from the outset how Gothic tropes, like the uncanny, might be applied in general terms to Amy Winehouse's story and then more specifically to "Back to Black". My approach here is at least partially literary, similar to Freud, where references to literature formed part of a strategy to elucidate the darker psychic reality and specificities of the human existence. Here, and in the following sections on Winehouse as "Captive Heroine" and "The Gothicized body," valuable connections between the Gothic, identity, the feminine, Female Gothic and the unconscious help to broaden the analysis and prepare the ground for the textual analysis which follows, using both semiotic and ethnomusicological approaches. Drawing upon the idea of the psychogeographic, I will then develop this Gothic approach with specific reference to the locale in which the video was shot and situate these elements in relation to Amy Winehouse's story. Psychogeography is an area of research which generally focuses on "the relationship of the urban environment and the psychic, daily lives of individuals" (Long 2013: 50). British author lain Sinclair describes the psychogeographical as bringing together "strange coincidence and serendipity" with more conventional methodological approaches (Sinclair August 2013, interview with author).

The approach adopted here draws upon imperatives from the Female Gothic tradition. These strongly relate to a "crucial concern with questions of female economic ownership and agency" (Heise-Von der Lippe 2009: 175); elements which are also central to Amy Winehouse. Meaning here is often conveyed in terms of metaphors:

(F)emale Gothic metaphors have enormous power to convey women's experience of living in a culture which historically denied them legal status as "subjects" within marriage, and which has continued to make women feel that they are denied a full subjectivity. Such metaphors offer an emotive and compelling way of challenging established and "rational" hegemonies and "theorizing" alternative truths which may be difficult to express in other ways. (Wallace 2009: 38)

Accordingly, I have considered elements of the "Back to Black" video as symbols with reference to the tradition of Female Gothic writing. Diana Wallace notes that in A Vindication of the Rights of Woman (1792) Mary Wollstonecraft "signals the issue of women's legal non-status through a Gothic metaphor of imprisonment" (Wallace 2009: 32). Similarly, she draws our attention to the way in which a range of feminist thinkers from Margaret Cavendish through Mary Wollstonecraft, Virginia Woolf, Hannah Gavron, Adrienne Rich, Luce Irigaray and Sarah Kofman, to Diana Fuss and Judith Butler "use Female Gothic metaphors to theorize women's position or, rather, repression within history and society" (Wallace and Smith 2009: 7). I wish to consider Amy Winehouse's "Back to Black" with the complex interchange between the Female Gothic and feminism in mind and, in doing so, to further widen the diversity and range of texts which might be included under the heading of the Female Gothic.

\section{The light that burns twice as bright burns half as long...}

The life and music of Amy Winehouse can be understood in Romantic terms: that is, a number of ideas rooted in the nineteenth century which continue to condition 
contemporary understandings of music. Many of these elements connect with the more particular Gothic associations which I wish to explore. There are several possible areas here, but I would like to focus upon Amy Winehouse's untimely death. I want to do this not least because this is a recurring motif in Romantic ideological understandings of western culture where "great artistry is perceived as arising from pain and tragedy" (Dibben 2009: 328) but also because of the cognate Gothic preoccupation with death. The Romantic, untimely death is a narrative type which brings together creativity, fame and the Gothic. It achieves a special currency through the death of Byron in 1824 (ibid.) and develops further in the Romantic period as a range of creative people expire at a relatively young age: Emily \& Anne Brontë, Keats, Shelley, and Schubert. Winehouse's death can be seen as part of this Romantic lineage but it also places her within a particular Rock collectivity known as the "27 club" (Sounes 2015).

There is an uncanny resonance to the notion of untimely death; one which links it with the Gothic and which can usefully be discussed with reference to Freud. Whilst the early death of music artists can be explained away in a number of rational ways (the pressures of fame, lifestyle and drugs) there is a sense here in which older, discarded, suspicious beliefs are at work in the form of the uncanny. Bennett and Royle suggest a list of the forms which the uncanny can take; this also includes "strange kinds of repetition", "the sense that things are fated to happen" but also death: "in the sense of something at once familiar...and absolutely unfamiliar, unthinkable, unimaginable", a point of ending which is always in some sense simultaneously "survived" as the record of a life, real or fictional, continues to "live on" (Bennett and Royle 2007: 131). Freud's notion of the uncanny foregrounds the strangeness of the 27 club and its Gothic nature. Death in this context is entirely predictable: it reoccurs. The 27 club is then a form of haunting, an ongoing preoccupation with "what is dead, what survives and how things are revived" (Warwick 2007: 36). I will refer back to Freud's essay later on, but my references to the uncanny at this stage form part of my intention to consider aspects of Amy Winehouse's life in Gothic terms.

\section{Amy Winehouse as captive heroine}

Before moving on to consider "Back to Black" as musical text, I want to develop the connection between Amy Winehouse and ideas of the Gothic which emerge from a literary context. The Gothic novel, rather like the experience of many female artists in the music industry, does not generally evidence a significant level of empowerment on the part of its female participants; there is often a sense here of their routinely being at the mercy of dark forces and venal male figures. As Whiteley suggests, "The music business was, and largely remains a man's world" (2003: 910). Whilst Amy Winehouse's narrative is not fictional, the events and circumstances of her life can be mapped with reference to specific Gothic literary tropes and metaphors. Like the 27 club, discussed above, there is a sense here of the uncanny: repetition or recurrence of character types, events and phenomena redolent of the return of pre-modern irrational forces. In this section, I want to work through some of these elements but, at the same time, open up the discussion with further reference to the psychogeographic.

The Gothic novel often presents its central female character as a "damsel in distress", literally imprisoned within a dungeon or incarcerated in a castle. The source of this distress is typically an evil duke or other patriarchal figure which form part of the "villain-victim structures of the Gothic tradition" (Wallace and Smith 
2009: 10). In terms of the Female Gothic this has been seen as metaphorical, a code for concerns over repression and agency. Such a metaphor can be extended to the experiences of female artists in the music business. Whilst there are rarely occasions in which the musical heroine is actually imprisoned, the careers of stars, like Amy Winehouse, impose a set of invisible or even structural constraints. The framework in which the successful artist resides is conditioned by the fact they are a commodity which must be sold successfully. Here, appearances and touring present real problems for artists who struggle to deliver consistent performances of quality; there is a strong sense from the available biographical material, together with the film "Amy" (2015), that this was a concern to both the singer and her minders. It's also important to bear in mind that Winehouse's musical output was comparatively small taking the form of just two albums: Frank (2003) and Back to Black (2006). In his biography, Newkey-Burden (2011) refers not only to her dissatisfaction with the music she produced but also the pressure to generate more material. There is here a powerful sense of the commercial imperatives of the music industry, which require its employees to remain focused, creative and reliable. Moreover, the strictures imposed by this existence, whilst invisible, might be thought of as carceral and, via this analogy, confer a distinctly Gothic complexion upon the female artist who is subject to the patriarchal authority of the industry males who surround her.

Aside from the structural constraints of the music industry, I also suggest that there are other aspects of the artist's existence which might be considered as prisonlike. These have to do with the celebrity experience, the psychological pressures this creates and the ways in which singers, like Amy Winehouse, have attempted to cope with it. As Chris Rojek notes: "constantly being in the public eye produces psychological difficulties and trauma" (Rojek 2001: 80). He notes that the tension between the I (the veridical self) and the Me (the self as seen by others) (ibid.: 11) produces a Gothic dynamic in which "the public face becomes a living tomb of staged personality" (ibid.: 80).

Biographies and documentaries all reference Winehouse's vulnerability, drug addiction and the influence of her husband - a possible parallel with the "oppressive duke" (Sutherland 1999: 337) or patriarchal villain often found in Gothic novels. Mitch Winehouse's (2013) account of her life paints a very manipulative and controlling picture of Blake Fielder-Civil, a figure who introduces her to drugs. There is a strong sense in his account of her having to be continuously rescued variously from both Fielder-Civil ${ }^{1}$, and herself. At the same time, drugs, her eating disorder, and ultimately her death, speak to her own coping strategies and "flight from tyrannical imprisonment" (Milbank, 2009: 77). The strong presence and influence of men in her life extend the possibilities of the confinement metaphor to include "patriarchal authority" (ibid.).

I have been arguing here that the music industry, and the kinds of lives led by artists, especially female, can be understood via the analogy of Gothic incarceration. This is a point which can be more literally developed with specific reference to place and the architecture of confinement. As I've already mentioned, biographical accounts of her life tell of the efforts by family and friends to make the singer get her drink and drug habits under control. Famously, she sings about this pressure in the song "Rehab" (2006). In this case, the facilities involved have a striking Gothic resonance, one that is entirely consistent with the Victorian era if we locate clinics and rehab facilities within a tradition of treating the mentally unwell. It is also possible to consider ideas of containment and control in terms of the Female Gothic and the historical fact of routinely institutionalizing women who do not conform. Of particular note is the time Winehouse spent at the Priory in 
Southgate. ${ }^{2}$ She also spent time on Osea Island in the Thames estuary, another expensive and exclusive rehabilitation facility. The causeway for Osea is used in the film "Woman in Black" (2012), to connect the mainland with a troubled fictional Gothic island. These elements and connections can be said to story and Gothicize Amy Winehouse, constructing a modern Gothic tale of confinement situated within a wider set of psychogeographic coordinates.

\section{The Gothicized body}

A particular aspect of style, characteristic of the Gothic, is its "dramatic contrasts of splendor and squalor, the beautiful and the grotesque" (Honour 1981: 161). Halberstam explains, in her study of the horror genre, that the Gothic is "a narrative technique, a generic spin that transforms the lovely and the beautiful into the abhorrent and then frames this transformation within a humanist moral fable" (Halberstam 1995: 22). Anya Heise-Von der Lippe notes that "The female body has been at the centre of definitions of the Female Gothic" (2009: 166): the author's body becoming replaced within the text by bodies which range from "professional victim to the monstrous feminine" (ibid.). Whilst Amy Winehouse's story can hardly be described as a humanist moral fable, there is a sense of Romantic deterioration here. The reasons for this descent are complex but what interests me is the way in which this process can also be thought of in terms of the ugly and the grotesque. Rojek notes of celebrity descent that it is established "by routines of behaviour that centre on the mortification of the body. Thus, celebrities may become anorexic or balloon in weight, develop phobias about being in public places, succumb to narcotic addiction or engage in public displays of drunkenness" (Rojek 2001: 80). I want to explore the relevance of this idea in relation to Amy Winehouse and to consider its Gothic significance in terms of her appearance.

A review of one of her American gigs described it as "Ronnie Spector meets the Bride of Frankenstein" (in Winehouse 2013: 78). Similarly, in Mick O'Shea's biography of Amy Winehouse he also connects the Gothic and the celebrity body by describing her tale as an alternate spin on "The Picture of Dorian Grey" (O'Shea 2012: 10). These are just two instances of her narrative being framed in Gothic and religious terms which reference the body. Alongside the image of Amy Winehouse as Gothic heroine, less prepossessing possibilities appear: the grotesque, the monstrous, even that of the zombie or living dead. This is to draw attention to the physical phenomena that trace the process of mortification and the way in which personal crisis can be exacted on the body in the form of tattoos, weight loss and addiction.

However, the social significance or meaning of tattoos is far from fixed. Research has suggested that they are variously understood to be an index of rebellion, individual expression and a need to exercise control over the body (Kang and Jones 2014: 267). Newkey-Burden, in his biography of Winehouse, noted that "Janice Turner was less kind in The Times, writing that she [Winehouse] 'resembled a Barbie doll attacked by an additive-high, felt-tip wielding toddler'" (ibid.: 128). Halberstam argues that "the body that scares and appals changes over time" (1995: 8). Drawing upon the ambivalence regarding Winehouse's tattoos, and tattoos in general, I want to suggest that these took on the complexion of the grotesque, their proliferation on her skin consistent with the process of mortification. The Gothic significance of her tattoos also draws upon their situatedness at surface level. As Halberstam notes: 
(S)kin....with reference to certain nineteenth-century monsters, becomes a kind of metonym for the human; and its color, its pallor, its shape mean everything within a semiotic of monstrosity...skin houses the body and it is figured in Gothic as the ultimate boundary. (ibid.: 7)

In Gothic terms then, tattoos focus our attention on the skin affording this part of the body a semiotic significance: a text that recounts the broader Amy Winehouse narrative. The accretion of tattoos on her body depicted a curious admixture of values and personalities and the need to visualize them gathered in urgency as part of her celebrity descent; this "semiotic of monstrosity" (ibid.: 7) signified a growing sense of inner crisis (ibid.). Some of her tattoos clearly express a Romantic artistic mindset but, at the same time, this uncanny use of body as text revealed a need to inscribe, fix and wear upon the skin the characters who formed part of her own Gothic melodrama. Winehouse's tattoos referred to a variety of people who were important in her life and, in a sense, became an uncanny surface upon which the key, often conflicting, personalities in her life became inscribed: Blake, her father (Mitch) and her grandmother (Cynthia) all feature here.

In her essay on the "The Abject and Grotesque", Kelly Hurley (2007) develops the latter term with reference to Rabelais, Kristeva and Bakhtin. Here, citing Bakhtin, she notes that the grotesque involves "the lowering of all that is high, spiritual, ideal, abstract" to the "material level" (Bakhtin 1984: 19 cited in Hurley 2007: 138). Again, this polarization upon the body, I want to suggest, is consistent with Rojek's comments above about mortification. Hurley develops this idea of materiality, arguing that the grotesque is characterized by phenomena that breach boundaries, that which disturbs order and the system: "the body's secretions and excretions are abject, breaching the boundary between the (seemingly self-contained) body and the external world" (2007: 138). These ideas are consistent with Rabelais' notion of the grotesque body, one which "copulates, defecates", breaks into boils, urinates, sweats, "overeats" and retches (Bakhtin 1984: 319 cited in Hurley ibid.). To characterize Amy Winehouse in these terms is arguably extreme although there were media representations in the latter stages of her life which consistently portray her in exactly this way. Moreover, a study by Berkers and Eeckelaer (2014) suggests that the press is complicit in framing these stories in such a way that female performers are unable to excuse their behaviour with reference to a rock ' $\mathrm{n}$ ' roll lifestyle (which their male counterparts can). One of these stories contained images of her and her husband in the aftermath of a drunken, drug related binge at the Sanderson Hotel on London's Berner street on Friday 24 August 2007. Here, unforgiving media images showed the star looking tired, thin, with the makings of a black eye and cuts in several places on her body, including her feet (as noted by O'Shea 2012: 138). This and other incidents were presaged by Winehouse's appearance on Never Mind The Buzzcocks on 16 November 2006 (ibid.: 105) when she was so drunk that she slurs and seems, at times, unable to stand, providing a marked, even uncanny, contrast with an earlier appearance on the show in 2004. Spurred on by host Simon Amstell, at one point Winehouse simply spits onto the ground. Another story tells of her receiving an expensive dress, by way of apology, from designer Alexander McQueen; she is reported to have spat on and then burned the item (Wilson 2015: 291). All of these are instances of the kind of celebrity descent to which Rojek refers but also, I want to suggest for the purposes of this discussion, the performance of a kind of Rabelasian grotesque.

Developing Rojek's idea of "mortification" (Rojek 2001: 80), the extreme changes which took place in Winehouse's body, particularly in the last few months of her life offer a further instance of Bakhtinian grotesqueness: "the idea of a human 
body without proper boundaries, a body that is composite, unfinished and surreally disproportionate" (Hurley 2007: 140). Winehouses's body "transgresses its own limits" (Bakhtin 1984: 26) with a breast implant operation in 2009; it also becomes bulimic, undersized and underweight. Hurley (2007: 141) argues that "grotesque affect" is like Sigmund Freud's "uncanny", paralleling Gothic horror in terms of "a world which breaks apart" (Kayser 1966: 31 cited in Hurley 2007: 141). Here, Winehouse's appearance and behaviour become just that: the familiar in terms of a healthy well-adjusted individual becoming defamiliarized to both fans and family. Indeed, the images of the singer in the last couple of years of her life became increasingly troubling and, even monstrous, in the sense that "the monster blurs the boundary between death and life" (Hurley 2007: 138). Alongside concerns expressed by her family, Winehouse had reportedly predicted that she would die at twenty-seven and this sense of already being dead compounded the feeling of the uncanny generated by her deteriorating appearance (Sounes 2015: 155). Her mother Janice remarked "I've already come to terms with her dead. I've steeled myself to ask her on what ground she wants to be buried, in which cemetery" (O'Shea 2012: 162). I suggest that such descriptions Gothicize Winehouse by invoking a particular motif: the living or walking dead, a kind of urban revenant. Drawing upon the Female Gothic, there is also a sense in which the body becomes a strategy, a means of both exercising control and expressing what cannot be vocalized in other ways. Here, bulimia becomes part of a process of mortification: the subjugation of the basic desire to exercise autonomy and determine one's own subjectivity.

\section{"Back to Black" as musical text}

Having mapped out some coordinates of Amy Winehouse's life and career in terms of the Gothic I now want to develop this discussion with reference to "Back to Black". This forms part of a legacy of pop songs which would not be described formally as a minor blues but which derive from it. Tracks like "Black magic woman" (Fleetwood Mac, 1968) or B. B. King's "The Thrill Is Gone" (1969) are clearly related to Bill Withers' "Ain't no sunshine" (1971) or The Doobie Brothers' "Long train runnin" (1973). Written in D minor, a mode (aeolian) often associated with death (Whiteley 2005: 86), the themes typically dealt with in such tunes concern loss: the uncanny or melancholy presence of something once desired and familiar which, in reality, no longer exists. Structurally, "Back to Black" offers a familiar verse, verse, chorus, verse, bridge, chorus format. Similar to more traditional minor blues tunes, the chord progression in both verse and chorus rises from the tonic chord ( $\mathrm{D}$ minor) to the 4th $\mathrm{G}$ minor returning to the tonic via the 6th chord (sub-dominant) and then the 5th dominant chord (a substitute from the 5th degree of the related $D$ harmonic minor scale). The contour of this sub dominantdominant-tonic resolution, or turnaround, serves as an analogue for the narrative return to "black" depicted by the lyrics; it functions here as what Philip Tagg has dubbed a kinetic anaphone (2012: 498). Similarly, the melody underlying the lyrics "go back to" descends from a C\# ending on the dominant degree of the D minor scale (A). The bridge then serves to reinforce the emphasis on "black", the word receiving bar length repetitions accentuated by the transition to half time and a "Leader of the Pack" (1964)-style kick drum. Similarly, the repetition of the final line of the bridge ("I go back to") reinforces the idea of reverting to an earlier state. Before this section, and elsewhere, the key term "black", signifying the single life 
but also heroine, undergoes an uncanny series of omissions before its saturation in the bridge: it appears previously only once at the end of the first verse.

"Back to Black's" derivation from the blues genre is significant: it locates it as part of a musical lineage rooted in the south of the USA, a region which, as Peter Doyle notes, has generated a tradition of "southern Gothic" (2005: 99). Middleton has written that the "rural bluesman was typically a wanderer, often a social misfit or problem, and regarded by many with distrust, equivocation or even as a demonic figure" (2000: 146). The mythical story of legendary bluesman Robert Johnson reveals the, often uncanny, nature of such narratives: forces which most would wisely leave untouched are disturbed. Here, the song "Cross Road Blues" (1937) is considered to be autobiographical; legend has it that Johnson sold his soul to the Devil, part of a Faustian pact whereby he would obtain ability to play the guitar (Walser 1993: 9). Whilst I am cautious about uncritically reinvoking one of the "competing discourses" (Schroeder, 2004: 57) about Johnson, I do want to argue that the elements discussed here can be connected as part of a Gothic analysis. Here, blues derived music, like "Back to Black", forms part of a pre-existing tradition which cannot be seen in isolation from its cultural antecedents. Moreover, this mystical motif of the rural bluesman is similar to the "stock Gothic character" (Spooner 2007: 42) of the 'Wandering Jew' which emerges in a variety of literary contexts. For Winehouse both tropes invoke ideas of containment and punishment. In her discussion of Kate Bush, Sheila Whiteley suggests that "[Wuthering Heights] draws on the traditional concept of the woman who is punished for her sexuality, her wilder side, so drawing not only on the Gothic, but also on the mythological" (2005: 73). Equally, an analysis of "Back to Black" speaks to anxieties about errant female behaviour and the potential for this to be sanctioned in various ways.

Lyrically, "Back to Black" supports the Gothic elements of the song's structure and harmony. Here, central motifs of death, the uncanny and recurrence are evidenced in the chorus where the singer tells us that she "died a hundred times". Similarly, contrasting elements of the grotesque and the beautiful manifest themselves in a variety of ways. As Gary Mulholland noted in an Observer article based on an interview with Winehouse: "Sings sophisticated: talks rough. Musically mellow: lyrically nasty" (Mulholland 2004). In stark contrast to the poetic restraint which characterizes the sixties music from which Winehouse drew her inspiration, her own writing reveals the lyrical candour of hip-hop; a music which had also had such a profound influence on her writing (Brooks 2010: 44). In "Back to Black", Amy Winehouse is not content to remark upon her ex's return to his ex-girlfriend whilst she goes back to "Black" (what she knew before). Here, we are told that he "kept his dick wet" with a lyric which typifies the contemporary, street-direct turn of phrase which is characteristic of her songs. In her account of Winehouse's voice, Daphne Brooks (2010) looks critically at the incongruity of the individuated world portrayed in her lyrics and the civil rights era of hope and change out of which 1960s Black music emerged. Here, the propriety of sixties Black music to which Brooks alludes references a modern, humanistic message of hope and progress; an uncanny contrast, to the lived experience or hip hop-infused Gothic underside of Winehouse's London. Similarly, Allan Moore in his comments on "Rehab" (2012) draws attention to critic Joe Queenan's remark that "the music of the Sixties was fine...but the lyrics were inane and the age of innocence is over" (Queenan 2008 cited in Moore 2012: 209). In this way Ronson/Winehouse's faithful reproduction of, as Brooks puts it, a "compositional style of a bygone era, note for note" (2010: 46) forms part of an uncanny contrast between grotesque (the cynical directness of 
hip hop) and the beautiful, understood as the innocence and hope of sixties Black music.

In contrast to Brooks, and drawing again upon Whiteley, it is possible to locate this instance of grotesqueness in terms of the different ways in which female creativity is conceptualized. Here, Whiteley talks about "external voices" informing the work of Kate Bush, Tori Amos and Bjork: the invoking of "spectral or other worldly images" (2005: 117). She also states that "the unconscious has long been central to feminist accounts of femininity, not least because it represents a resistance to identity" (ibid.: 117). This references Helen Cixous' concept of Écriture féminine and valorizes "unleashing an unruly babble of desire and disgust" (2005: 117) as a source of female creativity. Many of these concepts deployed by Whiteley demonstrate Gothic overtones, but it is this final idea of language as a distinctly bodily product which casts a different light on what might appear on the surface to be gratuitous crudeness. It is precisely this Gothic excess which speaks to female expression and frustration, a tactical renegotiation of the "little girl" (Whiteley 2005: 65) label so often affixed to serious female artists.

In production terms, "Back to Black's" vocal arrangement makes significant use of analogue spring and plate reverbs; reminiscent of the Wagneresque techniques used by Phil Spector as part of his "wall of sound" (Tingen 2007). It is one of several more recent recordings which "have balanced the use of technological applications from the past and present with the musician's creative practice" (Anthony 2015: 140). The creation of sonic space, in particular, is worth developing with reference to Doyle's work on echo and reverb (2005). He argues that music production in the 1950 s drew upon the use of echo and reverb in movies to create sound effects as part of a "realist supernatural" mode (2005: 106). Thus, "in sonically representing the uncanny, the mystical or supernatural, movie makers firmly assigned to echo and reverb new connotations of the mystically empowered 'loner hero'" (Ibid.: 106). Further stressing the uncanny association of these production techniques, Doyle notes that "echo effects so powerfully evoke notions of simultaneous aloneness and of invisible presences as to forcefully background social collectivist notions...in favour of 'inner' and supernatural issues - religious mystical or animist" (ibid.: 108). Similarly, Tagg stresses the semiotic potential of a recording's ambience via the notion of the spatial anaphone, something which can "provide insight into the mediation of mood in the music" (2012: 501). Such an interpretive framework, which derives originally from film, has therefore also come to inform the use of reverb in popular music. Furthermore, it is entirely consistent with the kind of Gothic sensibility which I am attempting to delineate here within the work of Amy Winehouse. More specifically and, drawing upon the elements discussed above, I want to suggest that "Back to Black", in terms of its production, harmony and structure, mirrors stock Gothic (and uncanny) themes of recurrence and repetition. These support the idea of continuously going back, a kind of Gothic return or reversion to a previous state: that of black.

\section{"Back to Black" as video}

The video for "Back to Black" (dir. Phil Griffin 2007) was shot largely in Abney Park cemetery in Stoke Newington, North London [see Figure 1]. Its central metaphor concerns the burial of the singer's heart and alludes to her failed relationship with Blake Fielder-Civil. Here, death and mourning serve as metaphors which are set against a Gothic backdrop: a chapel at the hub of a network of pathways lined with elaborate statuesque Victorian graves. 


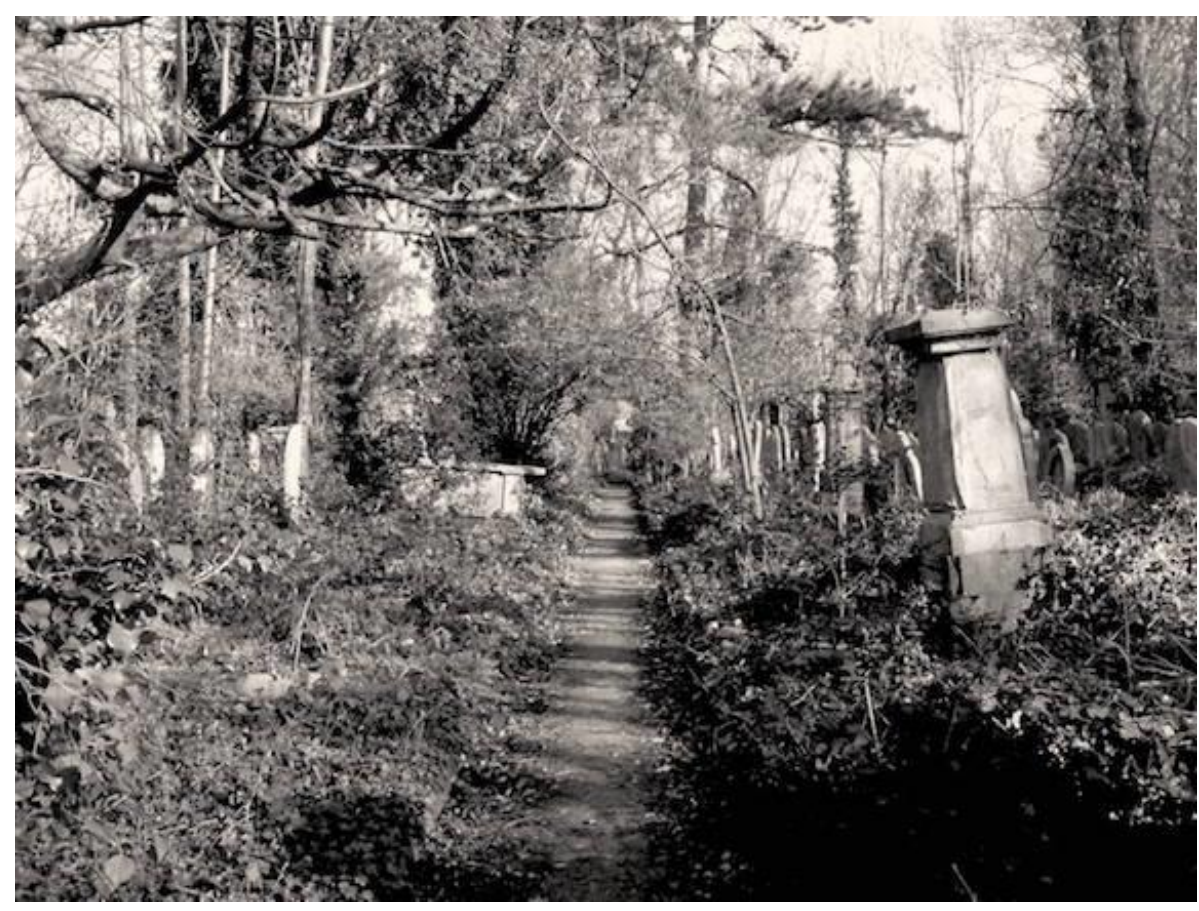

FIGURE 1. Abney Park cemetery, Stoke Newington, North London (photograph by the author)

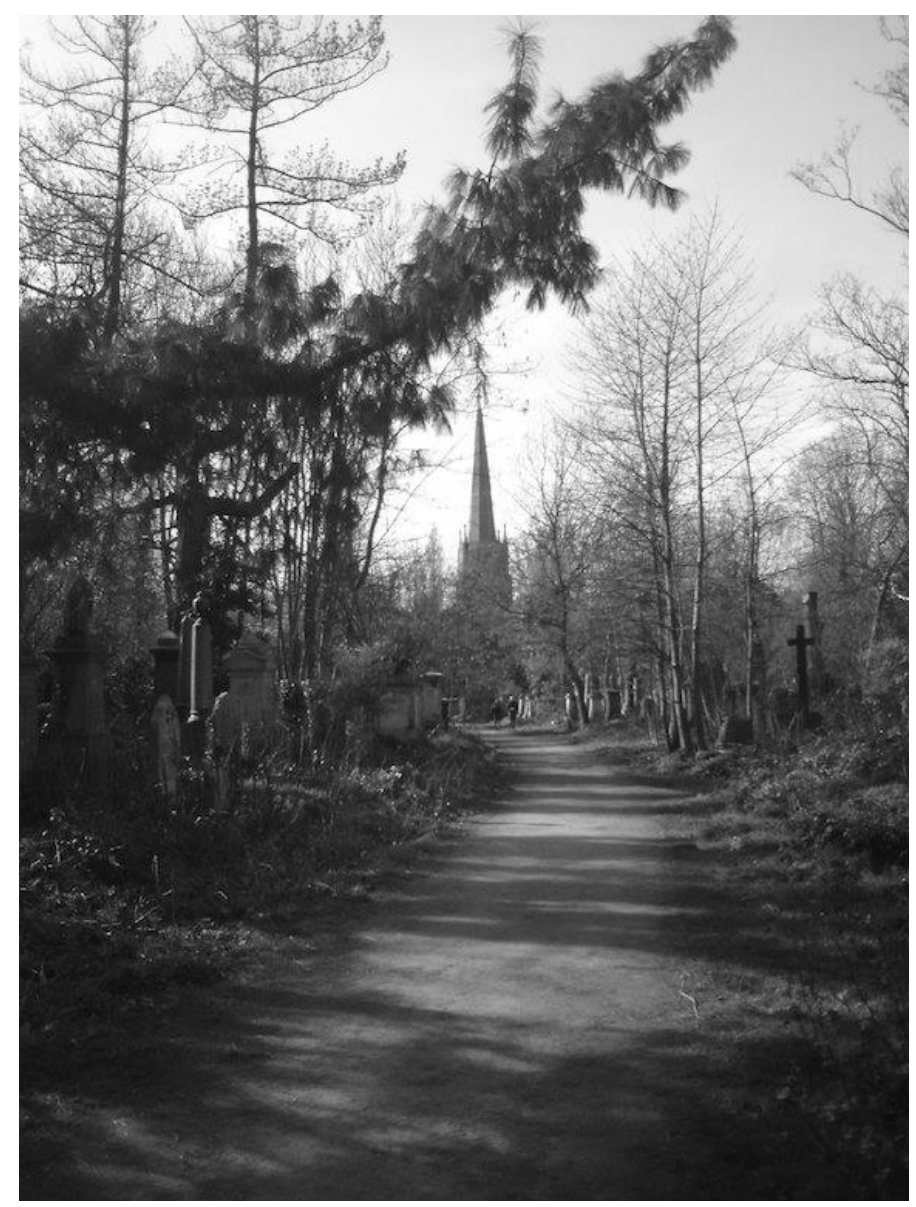

FIGURE 2. Abney Park cemetery chapel (photograph by the author)

|@j vol.8 no.1 (2018) 
In this choice of location there is a strong sense of continuity, which lain Sinclair remarked upon when I interviewed him in 2013: "There's always been a powerful Gothic element in Abney Park: the ruined church in the middle, headbangers, black magicians, 666, Crowleyite slogans painted all over that - it's had a tradition of that" (Sinclair 2013). For a long period, this chapel [see Figure 2] was fenced off to the general public; its dilapidation speaking both to the idea that "ruins are the chief conveyors of Gothic sentiment" (Clark 1970: 23) and the idea that, in male systems of representation, women lack adequate symbolization, existing only in a state of dereliction or abandonment (Wallace 2009: 37).

The Gothic nature of this text manifests itself in a number of different ways. Firstly, it is shot in black and white producing connotations of an earlier epoch of film and helping form a deliberately noir motif. Indeed, Winehouse's walk into Abney Park [see Figure 3] is reminiscent of the final scene in "The Third Man" (Carol Reed 1949) where Anna Schmidt (Alida Valli) disappears into the distance after her final exchange with Holly (Joseph Cotton). Fast forwarding thirty years, there is also a strong retro sense of the 1960s and, whilst it was made in colour, Peter Medak's 1990 biopic "The Krays" (2002).

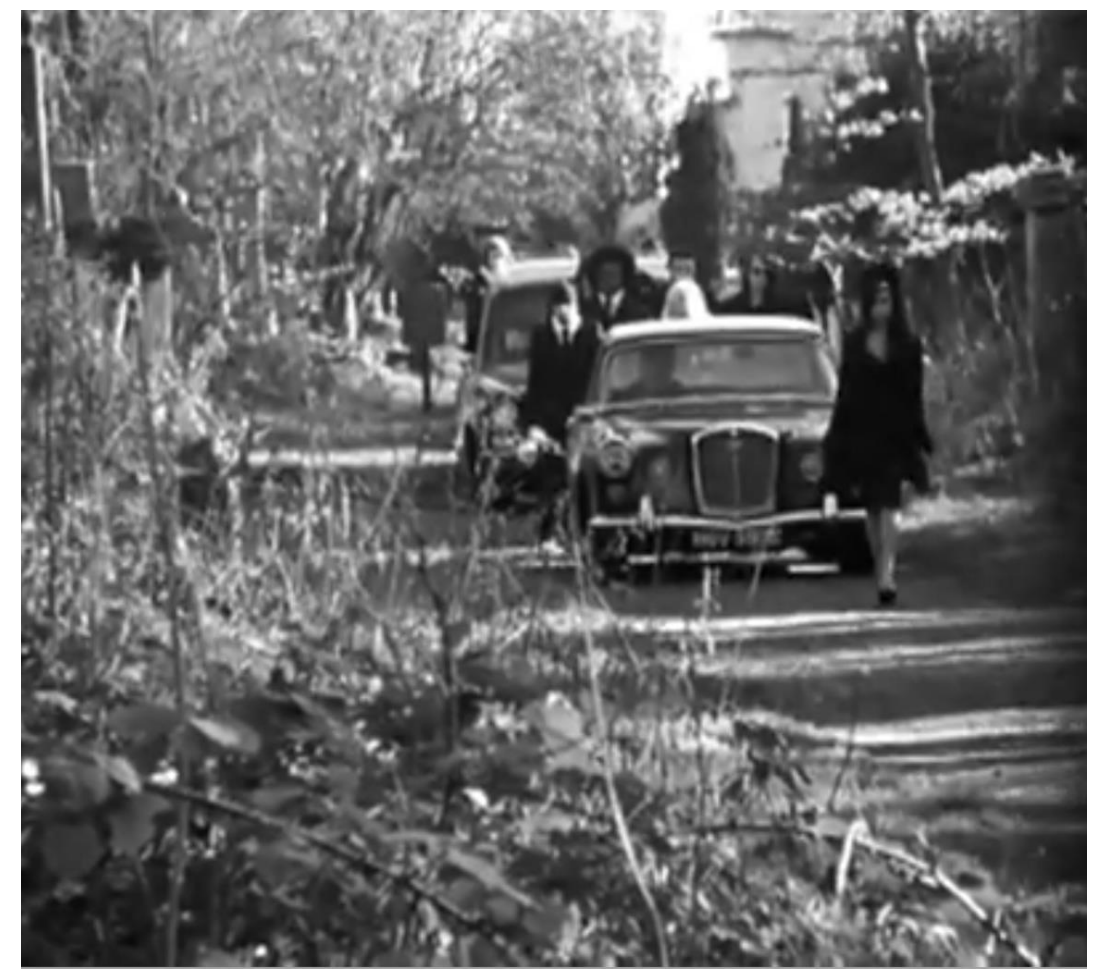

FIGURE 3. Funeral cortege makes its way into Abney Park. Still from the video for "Back to Black" (courtesy of Island Records).

In the opening shot of "Back to Black" two men are situated in the same front parlour with Amy Winehouse [see Figure 4]; one sits with his back to her whilst the other directly faces the camera. Even though there are only three people in this interior shot, it is a largely male gathering, not a collection of relatives; this could either be a tribe of henchman or possibly her band. Later in the video (dir. Phil Griffin 2007: 3.00-3.04) we see Winehouse, in mourning wear, in her 'widow's weeds' (Arnold 2007: 210) perched on the edge of her bed [see Figure 5]. 


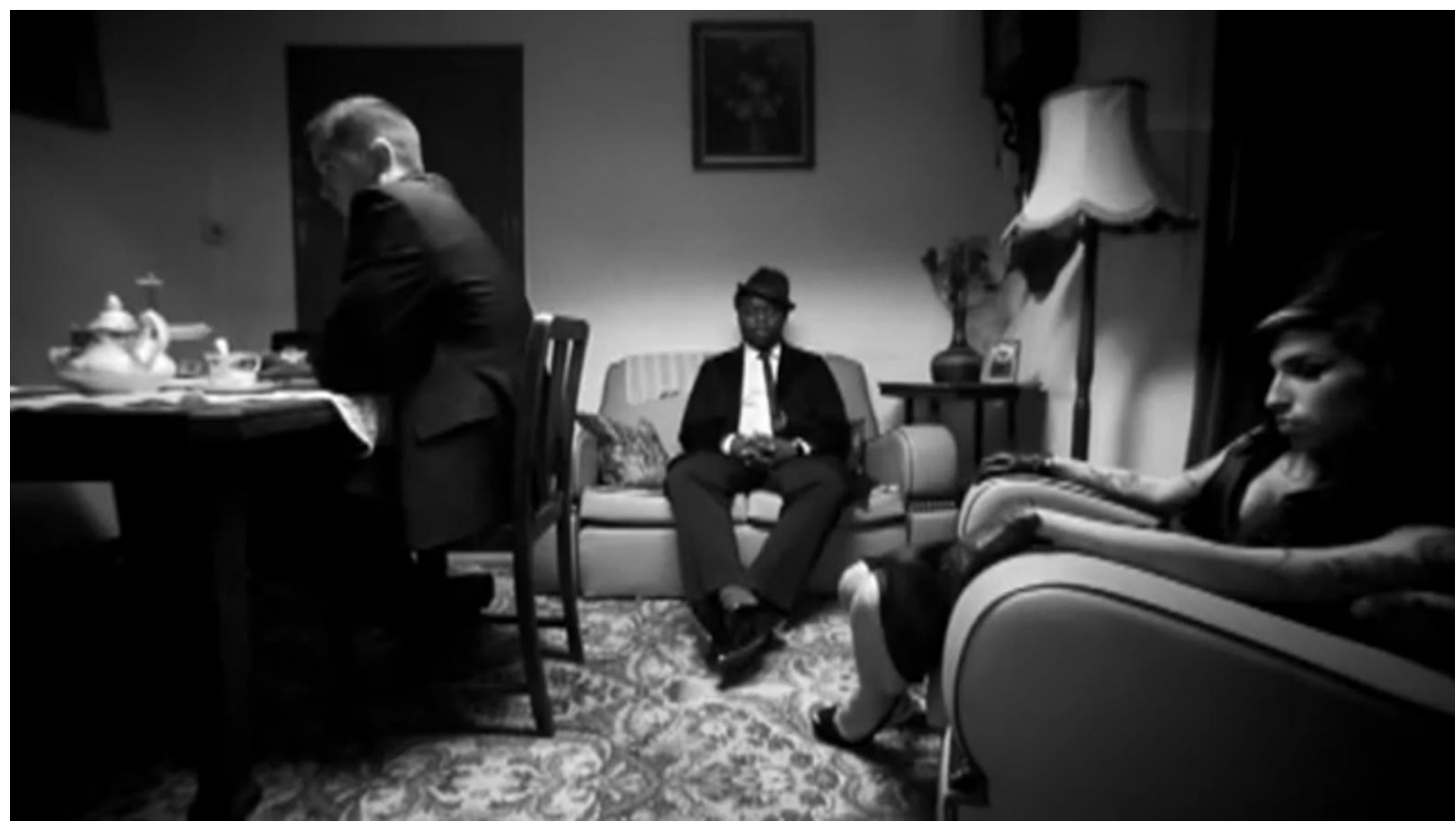

FIGURE 4. Interior mourning scene. Still from the video for "Back to Black" (courtesy of Island Records).

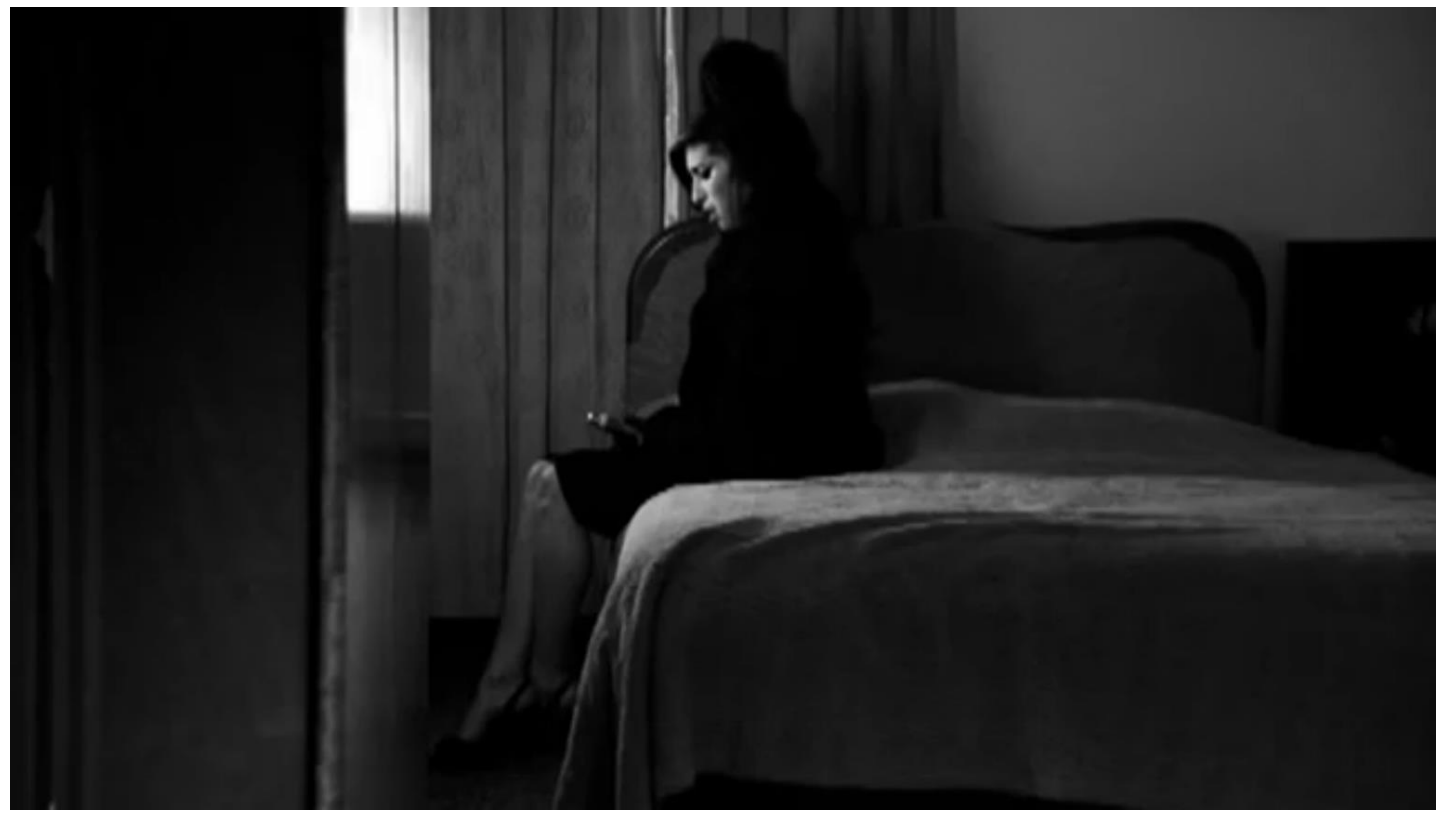

FIGURE 5. Amy Winehouse in her 'widow's weeds'. Still from the video for "Back to Black" (courtesy of Island Records).

We know that the burial is a metaphor, but there is also a possible portrayal in the video of Winehouse as a gangster's widow. The scale of the funeral, the livery and the cars confer a certain kind of kingpin status on the dead person or thing: too small to be a human being and, uncannily, never actually clearly defined or identified [see Figure 6]. 


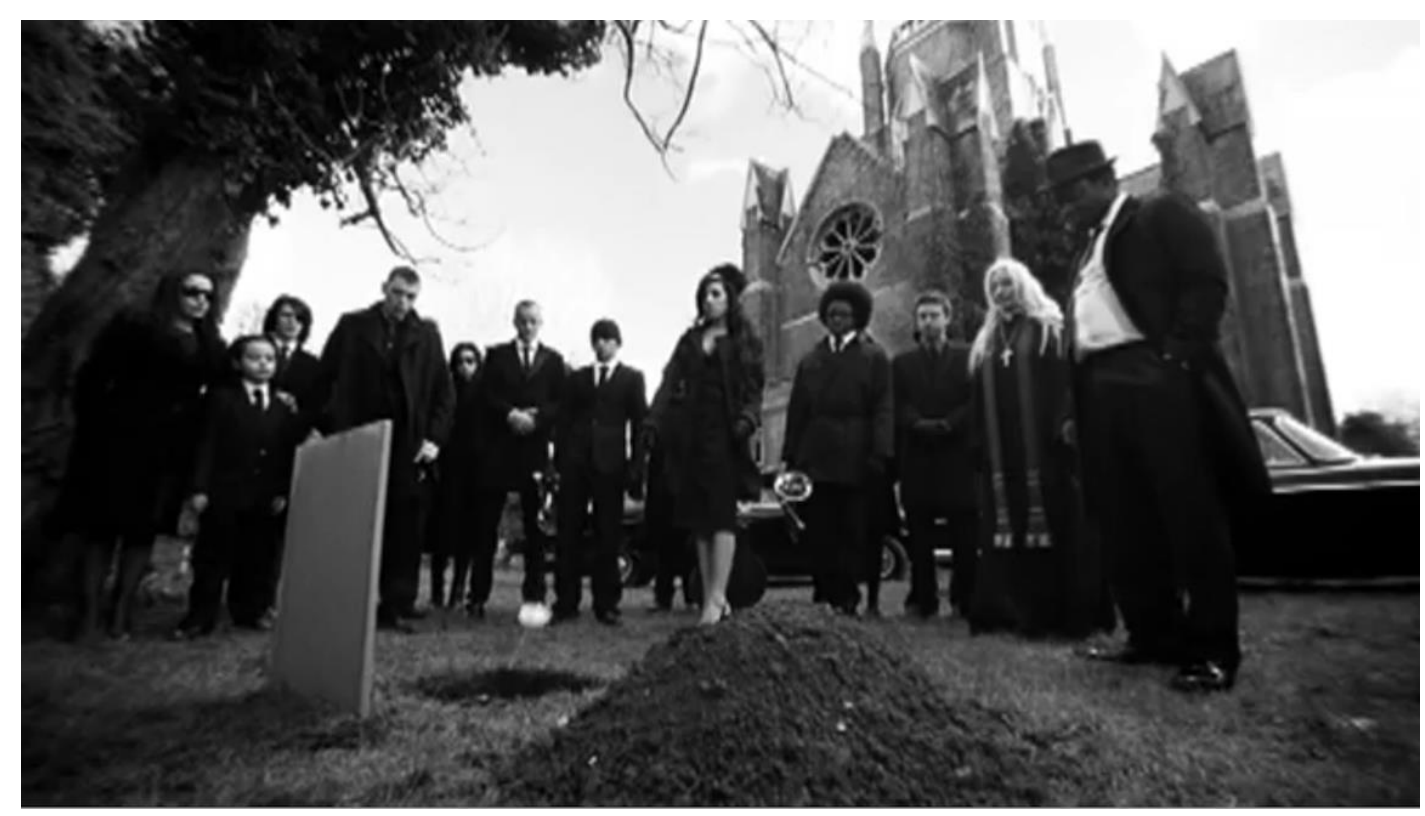

FIGURE 6. Burial of heart or 'thing'. Still from the video for "Back to Black" (courtesy of Island Records).

I say "thing" here firstly because burial is a particularly Gothic motif. Indeed, Eve Sedgwick has argued that live burial, in particular, can serve as a "metaphor for a repressed thing that threatens to return" (Sedgwick 1986: vi cited in Halberstam 1995: 19). It is also "a particularly powerful way of figuring the erasure of the female self within a construct of marriage which only allowed the legal existence of one person - the husband" (Wallace 2009: 30). So, the gesture of burial in this context references a range of key elements in the Winehouse narrative, not least the continuous return to drugs and alcohol which ultimately claimed her life. Moreover, it can also be understood in female Gothic terms via the association of burial with the interior space of the home. As Wallace notes:

Both men's houses and "their" beds - the domestic and sexual spaces, equally under male ownership - are compared to "graves" within which women are to be "buried", potentially "buried alive", a state which Freud called the "most uncanny thing of all" (Wallace 2009: 28-29)

There is a further aspect to burial in this context: the presence of a supernatural force that "mixes the horrific, the eerie and the comic in a manner specific to the grotesque mode" (Milbank 2009: 79). This is to say that whatever is being buried in the "Back to Black" video, the image is consistent with those found in other Gothic narratives. Milbank draws our attention to female automatons, oversized helmets, bleeding statues and bleeding nuns. She goes on to suggest that:

To be grotesque images must not merely be horrifying: they must provoke epistemological dubiety. As Geoffrey Harpham puts it, "they stand at the margin of consciousness between the known and the unknown, calling into question the adequacy of our ways of organising the world". (Milbank 2009: 79)

Here, the image of Amy Winehouse burying her own heart (and therefore appearing at her own graveside) signifies a crossing of the "the divide between 
death and life" (ibid.: 77) and adds yet another to the list of Gothic tropes at play in this particular story.

The narrative in the "Back to Black" video is largely generated by the song itself with the lyrics supported and framed by visual connotational meanings. However, I want to suggest here that the narrative uncertainty of the video is consistent with ideas of the Gothic. The elements referenced above also contribute to the same sense of the uncanny which I have been developing in this article. In German, the word uncanny is usually translated as unheimlich, a term that, as Freud (1919) suggests, can also be interpreted literally as "unhomely". Used in this sense, the term refers to the opposite of heimlich ("homely"): unfamiliar or unsettling. However, Freud also talks about a second meaning of heimlich, one which refers to "that which is concealed and kept out of sight" and "hidden or dangerous" (Freud 1919: 4), but where the use of its opposite (unheimlich) does not necessarily mean exposed or in view. In tracing the etymology of what appear to be opposing terms, Freud indicates their ambivalence; that their meanings begin to coincide. Put simply, the use of uncanny (unheim/ich) comes to describe something homely and familiar which contains the potential to conceal or become that which is frightening, dangerous or even monstrous. As Halberstam notes (1995: 15), nineteenth century Gothic often chose to focus upon the home and its personalized spaces, like the bedroom, as settings; literally and symbolically these are potentially unsafe even toxic spaces for women. Wallace notes, the house "is not just the domestic space, but itself a metaphor for the legal institutions of marriage and patrilineal inheritance (enacted through the 'bed') which erase the female name" (Wallace 2009: 29). In the video we see the juxtaposition of the homely, the living room/front parlour and bedroom, with the New Orleans style funeral procession located in the "outside" of the cemetery (Punter 2007: 134). As I've mentioned above, there is no feminine presence in shots of this home apart from the singer herself; this imbalance is uncanny. Thus, the interior spaces of the "Back to Black" video, and their inhabitants, offer both a sense of fear and familiarity: they are simultaneously heimlich and unheimlich generating a tension which is entirely consistent with the uncanny and the Gothic. Ultimately, Amy Winehouse was to die alone in her own house even though her body guard was close by. Halberstam notes that in the Gothic tale that "The monster... will find you in the intimacy of your own home" (Halberstam 1995: 15). In this way, Winehouse fell victim to the monstrous in the form of her addictions, and in this case, the demon drink.

\section{Stoke Newington and Abney Park cemetery}

Developing my discussion of Abney Park, I now want to proffer a psychogeographic overview of the cemetery's space, considering the relationship between people and place. In popular music studies, much of psychogeographic writing intervenes in existing debates about the musical mapping of cities like Liverpool and Sheffield. These are discussions that are often tied up with contemporary concerns about the creative industries and tourism (Long 2013; Lashua et al 2010). Whilst the discussion which follows takes advantage of wider definitions of psychogeographic, I want to move away from concerns about the musical mapping of cities towards what Philip Long calls "obscure places" (Long 2013: 51) - spaces like Abney Park cemetery. The following discussion is strongly informed by an interview I conducted with writer lain Sinclair, a leading figure in the field of psychogeography. Sinclair, who lives very close to the park, references it several times in "Lights out 
for the Territory" (2003: 13, 23-25, 84); he provides a central point of inspiration for this article.

A concept from the field of psychogeography which I want to apply here is attributed to the writer Peter Ackroyd: the idea of "genius loci" (Coverley 2010: 124). Mervin Coverley describes this as a "highly contentious and idiosyncratic theory of temporal and spatial correspondences within London...his recognition of zones within the city which display chronological resonance with earlier events, activities and inhabitants" (ibid.). There is a sense then in Ackroyd's work of a recognition that what happens in that particular locale can be interpreted in terms of what has occurred there before: "uncanny urban forces which are less than fully explicable, which appear to move along lines and trajectories" (Punter 2007: 134). Different parts of London then can be understood in terms of continuity, the product of an uncanny form of agency or spectral consciousness. Arguably this is a kind of Gothic sensibility which, in one form or another, informs most psychogeographic enquiry. As Catherine Spooner notes "Gothic as a genre is profoundly concerned with the past conveyed through both historical settings and narrative interruptions of the past into the present" (Spooner 2006: 9 cited in Heise-Von der Lippe 2009: 166).

I want to develop Ackroyd's concept with reference to Bakhtin's chronotope, a term which he uses to describe the way literature represents time and space. For my purposes, and cognate with Ackroyd's genius loci, I am interested in the way in which a particular motif, mood or setting (a Gothic cemetery in this case) can chronotopically conjoin different eras (middles ages, the Gothic revival and the "Back to Black" video) producing a "simultaneity of times" (Bakhtin 1981: 427). I also want to develop my analysis with reference to what Bakhtin describes as the chronotope of encounter. One such chronotope is that of the road, a metaphor (or metonym) where "time, as it were, fuses together with space and flows in it (forming the road)" (ibid.: 244). Bakhtin goes on to suggest that the road carries a levelling function where "the spatial and temporal paths of the most varied people representatives of all social classes, estates, religions, nationalities, ages - intersect at one spatial and temporal point" (ibid.: 243). Moreover, this is a space where "people who are normally kept separate by social and spatial distance can accidentally meet; any contrast may crop up, the most various fates may collide and interweave with one another" (ibid.). I want to draw upon this metaphor in conjunction with another of his chronotopes: the castle. This motif, he suggests, especially in the Gothic novel, is "saturated through and through with a time that is historical in the narrow sense of the word, that is, the time of the historical past" (ibid.: 246). Here, historical time becomes foregrounded via a particular type of space and "it is this quality that gives rise to the specific kind of narrative inherent in castles and that is then worked out in Gothic novels" (ibid.). In this way, Gothic places and the mood they generate can serve to elide time and space by generating a certain historical intensity: "the organic cohesion of spatial and temporal aspects and categories" (ibid.: 246).

So, drawing upon Bakhtin's chronotopes of both road and castle together with Ackroyd's genius loci, I want to propose that the cemetery is significant in particular ways: firstly, as a metaphor (or metonym) in the sense that Bakhtin intends. Here, like the castle, the cemetery elides space and time as Winehouse becomes positioned within the kind of story that typically takes place in such a setting: it Gothicizes and locates her within "historical time" (ibid.: 246) but also provides a space of encounter. Additionally, there is the specificity of Abney Park itself and the presence of its own genius loci, the suggestion of uncanny resonances: energies which should have dissipated with the passage of time, which develop and inform 
the Amy Winehouse narrative. Therefore, I am suggesting that both psychogeographic (genius loci) and non psychogeographic elements (chronotope) at play in the "Back to Black" video, help facilitate a Gothic rendering of the Amy Winehouse narrative. They do this by opening up a number of possible meanings and associations that derive from a particular space and which in turn inform her story.

\section{Conclusion}

Throughout this article, I have Gothicized Amy Winehouse looking to sketch an alternative vision of her life and music. I have framed both her and her story in terms of a range of stock-in-trade literary characters and Gothic tropes. There are several reasons for subjecting her to this treatment. Firstly, this aims to extend the range of texts which might be included under the broader heading of Female Gothic. Here, the various themes and tropes which emerge from this literary genre speak to a sense of continuity in terms of the structural constraints and anxieties that women face in society: to deploy the Gothic in relation to Amy Winehouse is to give voice to gender related issues of power and autonomy. Amy Winehouse's story is part of this continuity but unfolds in a very particular way, one which embraces modern notions of stardom and other contemporary concerns. Accordingly, I would suggest that this is an instance of the way in which the Female Gothic adjusts and recalibrates itself; "Black to Black" and the story of which it forms a part illustrates the ways in which the pathway of success can still prove lethal for women. Winehouse's untimely death is a strongly Gothic motif which also speaks to the way in which women can be failed by both the structures and the people who surround them. Here, her mental currency and health deteriorate to the point that she becomes insignificant and powerless: "a tiny penny rolling up the walls inside".

As part of this discussion I have also foregrounded the notion of place with particular reference to the locale of Abney Park. Such an approach is a departure for popular music studies; this is deliberate. Here, I have boldly attempted an approach which is consistent with modern notions of the psychogeographic, and is entirely sympathetic to Romantic understandings of popular music: it privileges the irrational, the contingent and allows for a free flow of possible associations and meanings. We never listen to music in a vacuum but absorb it as part of a larger imaginary which is powerfully informed by a curiosity about and desire to acquaint ourselves with its makers and the places which have conditioned their creativity. The legacy of the Gothic in our understanding of art and artists (in this context music and musicians) continues to play a role. To a large extent this is to reach beyond more traditional biographical or textual approaches in favour of something looser. Here, I want to suggest that both the psychogeographic and Gothic afford a kind of license to think differently about and give voice to criteria which might not pass muster under a more positivistic analytical criteria. Indeed, such a sensibility has been a defining feature of The Gothic, a genre which has always had the facility to reinvent itself in successive eras with precisely this purpose in mind. As Milbank notes: "the Gothic became a particularly appropriate medium for many different modes of philosophical and theological investigation, pushing all the time at the limits of its own generic construction" (Milbank 2009: 94). 


\section{Endnotes}

[1] Fielder-Civil as husband is consistent with a modern Gothic preoccupation with the familiar (or heimlich) as a source of terror or dread. The husband who turns out to be a monster is a familiar Gothic trope which is played out in Hollywood thrillers like Sleeping with the Enemy (Joseph Ruben 1991) and What Lies Beneath (Robert Zemeckis 2000).

[2] Whilst Winehouse was not treated at the site, the flagship hospital of The Priory Group, Strawberry Hill was the Twickenham home of Horace Walpole, writer of 'The Castle of Otranto' (2014).

\section{Acknowledgements}

The author would like to thank Professor Keith Negus, Nathan Wiseman-Trowse, Paul Caplan, and lain Sinclair for their support and help in relation to this article.

\section{References \\ Bibliography}

Anthony, B. 2015. Creative Conceptualisation: Nurturing Creative Practice Through the Popular Music Pedagogy of Live Recording Production. IASPM@Journal 5 (1).http://dx.doi.org/10.5429/2079-3871(2015)v5i1.9en

Arnold, C. 2007. Necropolis. London: Pocket Books.

Bakhtin, M.M.-

1981. The Dialogic Imagination: Four Essays. (ed. Michael Holquist). Austin, University of Texas Press. 1984a. Rabelais and His World. Indiana University Press.

1984b. Rabelais and His world. trans. H. Iswolsky. Bloomington: Indiana University Press.

1986. Speech Genres and Other Late Essays. (Emerson C. and Holquist M.

Eds.). Austin: University of Texas Press.

Bennett, A. and Royle, N., 2007. Introduction to Literature, Criticism and Theory. Harlow: Pearson Education

Berkers, P. and Eeckelaer, M. 2014. Rock and roll or rock and fall? Gendered framing of the rock and roll lifestyles of Amy Winehouse and Pete Doherty in British broadsheets. Journal of Gender Studies, 23 (1), 3-17. http://dx.doi.org/10.1080/09589236.2012.754347

Brooks, D. A. 2010. "This voice which is not one": Amy Winehouse sings the ballad of sonic blue(s)face culture. Women \& Performance: a Journal of Feminist Theory 20 (1): 37-60. http/dx.doi.org/10.1080/07407701003589337.

Dibben, N. 2009. Vocal Performance and the Projection of Emotional Authenticity. In D. Scott Ed. Ashgate Research Companion to Popular Musicology. Farnham: Ashgate. 317-333.

Clark, K. 1970. The Gothic Revival. Third edition. London: John Murray.

Coverley, M. 2010. Psychogeography. Harpenden: Pocket Essentials.

Doyle, P. 2005. Echo and Reverb. Middletown: Wesleyan University Press.

Freud, S., 1919. The Uncanny. Reprinted in Sammlung, Fünfte Folge. [Trans. Alix Strachey.] Available at: http://web.mit.edu/allanmc/www/freud1.pdf Accessed 3

August 2018

Halberstam, J. 1995. Skin Shows: Gothic Horror and the Technology of Monsters. Durham: Duke University Press. 
Heise-Von der Lippe, A. 2009. Others, Monsters, Ghosts: Representations of the Female Gothic Body in Toni Morrison's Beloved and Love. In D. Wallace and A. Smith Eds. The Female Gothic: New Directions. London and Basingstoke: Palgrave Macmillan. 166-179.

Honour, H. 1981. Romanticism. London: Pelican Books.

Hurley, K. 2007. Abject and Grotesque. In C. Spooner and E. McEvoy Eds. The Routledge Companion to Gothic. London: Routledge: 137-146.

Kang, M and Jones, K. 2014. Why Do People Get Tattoos. In T. Anderson Ed. Understanding Deviance: Connecting Classical and Contemporary Perspectives. London: Routledge: 266-271.

Kayser, W. 1966. The Grotesque in Art and Literature. trans. U. Weisstein. New York: McGraw-Hill.

Lashua, B., Cohen, S. and Schofield, J. 2010. Popular music, Mapping and the Characterization of Liverpool. Popular Music History 4.2: 126-144.

Long, P. 2013. Popular music, psychogeography, place identity and tourism: The case of Sheffield. Tourist Studies 14 (1): 48-65.

Middleton, R., 2000. Introduction: Locating the Popular Music Text. In Richard Middleton Ed. Reading Pop: Approaches to textual analysis in popular music. Oxford University Press: 1-19.

Milbank, A., 2009. Bleeding Nuns: A Genealogy of the Female Gothic Grotesque. In D. Wallace and A. Smith Eds. The Female Gothic: New Directions. London: Palgrave Macmillan: 76-99.

Moore, A. 2012. Song Means: Analysing and Interpreting Recorded Popular Song. Farnham: Ashgate

Mulholland, G. 2004. Charmed and dangerous. The Guardian, 1 February. http://www.theguardian.com/music/2004/feb/01/popandrock.amywinehouse Accessed 18 July 2015.

Newkey-Burden, C. 2011. Amy Winehouse: The Biography 1983-2011. London: John Blake Publishing.

O'Shea, M. 2012. Amy Winehouse: A Losing Game. London: Plexus.

Punter, D. 2007. The Uncanny. In C. Spooner and E. McEvoy Eds. The Routledge Companion to Gothic. London: Routledge: 129-136.

Rojek, C., 2001. Celebrity. London: Reaktion Books.

Schroeder, P. 2004. Robert Johnson: Mythmaking and Contemporary American Culture. University of Illinois Press.

Sedgwick, E. 1986. The Coherence of Gothic Conventions. New York and London: Methuen.

Sinclair, I. 2003. Lights Out for the Territory, London: Penguin Books.

Sounes, H., 2015. 27: A History of the 27 Club Through the Lives of Brian Jones, Jimi Hendrix, Janis Joplin, Jim Morrison, Kurt Cobain, and Amy Winehouse. Cambridge, MA: Da Capo Press.

Spooner, C., 2007. Gothic in the Twentieth Century. In C. Spooner and E. McEvoy Eds. The Routledge Companion to Gothic. London: Routledge: 38-47.

Sutherland, J. 1999. The Novel. In W. Wu Ed. A Companion Guide to Romanticism. Oxford: Wiley-Blackwell. 333-334.

Tagg, P. 2012. Music's Meanings. New York and Huddersfield: The Mass Media Music Scholars' Press.

Tingen, P. 2007. Secrets Of The Mix Engineers: Tom Elmhirst. Sound on Sound, August.

https://www.soundonsound.com/sos/aug07/articles/insidetrack_0807.htm Accessed 10th June 2016. 
Wallace, D. 2009. 'The Haunting Idea': Female Gothic Metaphors and Feminist Theory. In D. Wallace and A. Smith Eds. The Female Gothic: New Directions. London and Basingstoke: Palgrave Macmillan. 26-41.

Wallace, D. and Smith, A. 2009. Introduction: Defining the Female Gothic. In D. Wallace and A. Smith Eds. The Female Gothic: New Directions. London and Basingstoke: Palgrave Macmillan: 1-12.

Walpole, H. 2014. The Castle of Otranto. Oxford University Press.

Walser, R. 1993. Running With The Devil. Middletown, CT.: Wesleyan University Press.

Warwick, A. 2007. Victorian Gothic. In C. Spooner and E. McEvoy Eds. The Routledge Companion to Gothic. London: Routledge: 29-37.

Whiteley, S. 2003. Ed. Sexing the Groove: Popular Music and Gender. London: Routledge 2005. Too Much Too Young. London: Routledge.

Wilson, A. 2015. Alexander McQueen: Blood Beneath the Skin. New York: Scribner.

Winehouse, M. 2013. Amy: My daughter. London: Harper.

Wollstonecraft, M. 1999. A Vindication of the Rights of Woman. Oxford University Press [1792]

\section{Discography}

B.B. King. 1969. "The Thrill is Gone" [vinyl], Bluesway/ABC Records. USA. Bush, Kate. 1978. "Wuthering Heights", The Kick Inside [vinyl]. EMI: London. Fleetwood Mac. 1968. "Black Magic Woman", English Rose [vinyl]. UK: Blue Horizon.

Doobie Brothers. 1973. "Long Train Running", The Captain and Me [vinyl]. Warner Bros. USA.

The Shangri-Las. 1964. "Leader of the Pack" [vinyl], Red Bird. USA.

Winehouse, Amy. 2003, Frank [CD] Island, UK.

Winehouse, Amy. 2006. "Back to Black", Back to Black [CD] Island, UK.

Winehouse, Amy. 2006. "Rehab", Back to Black [CD] Island, UK.

Withers, Bill. 1971. "Ain't no sunshine", Just As I Am [vinyl]. Sussex, USA.

\section{Videography}

Back to Black. 2007. Dir: Phil Griffin (Online video), http://www.youtube.com/watch?v=TJAfLE39ZZ8 Accessed: 16 November 2013

The Krays. 2002. Dir: Peter Medak. DVD. Universal Pictures (U.K.).

Never Mind the Buzzcocks. Series 14 Ep. 10, first broadcast on 8 March 2004. https://www.youtube.com/watch?v=vG4i-90Qgkk Accessed 5 August 2018

Never Mind the Buzzcocks. Series 19 Ep. 4, first broadcast on 16 November 2006. https://www.dailymotion.com/video/x5nea1 amy-winehouse-on-nevermind-the-buz music Accessed 22 March 2017.

Sleeping with the Enemy.1991. Dir: Joseph Ruben. [DVD] 20th Century Fox Home Entertainment.

The Third Man. 1949. Dir: Carol Reed. [DVD]. Warner Home Video (U.K.). What Lies Beneath. 2000. Dir: Robert Zemeckis [DVD]. 20th Century Fox Woman in Black. 2012. Dir: James Watkins. [DVD]. Momentum Pictures (U.K.).

\section{Interviews}

Iain Sinclair. 2013. Interviewed by the author, London, 23 August. 